DOI: https:// 10.15407/kvt195.01.049

UDC 62.50

MILIAVSKYI Yu.L., Senior Lecturer, Department of the Mathematical Methods of System Analysis

e-mail: yuriy.milyavsky@gmail.com

National Technical University of Ukraine

"I. Sikorsky Kyiv Polytechnic Institute"

37 Peremohy av., Kyiv, 03056, Ukraine

\title{
IDENTIFICATION IN COGNIIIVE MAPS IN IMPULSE PROCESS MODE WITH INCOMPLETE MEASUREMENT OF NODES COORDINATES
}

Introduction. Cognitive map is a popular way of modeling complex multivariate systems. Usually weights coefficients of edges connecting the cognitive map nodes are suggested by experts. But such a method is always inaccurate. In case when nodes coordinates are measured, there is the possibility for mathematical identification of these coefficients. However, the issue is that often not all nodes coordinates of a cognitive map are measured, but only a few of them. In this case the problem of identification is much more complicated.

The purpose of the article is to research and develop a method for identifying weights of cognitive map nodes in case when number of nodes is known, but not all of them are measured.

Results. Identification method based on 4SID method is suggested. It allows finding some realization of the system equivalent to the original cognitive map in its outputs, with the control observation matrices remaining unchanged. Invariants of the original and identified systems are analyzed. Practical example of identifying a cognitive map of an IT company is considered. It is shown what the accuracy of the suggested method depends on and under which conditions it is applicable.

Conclusions. As demonstrated in the research, the proposed method of identifying cognitive maps achieves almost full coincidence of measured coordinates between the original and the identified systems, although the incidence matrices themselves may not be equal. Invariants of the system, specifically eigenvalues, are identified with sufficient precision if the problem is well-conditioned, i.e. with sufficient number of measurable coordinates, sufficient number of measurement periods and low level of measurement noise. If these conditions are not fulfilled, the identification results become incorrect.

Keywords: cognitive map, identification, 4SID method, unmeasurable coordinates. 


\section{INTRODUCTION}

Cognitive map (CM) is a weighted digraph that reflects basic concepts of a domain area and relations between these concepts via nodes and edges connecting them [1]. This paper continues the previous study [2] concerning an important recent problem of CM identification. Usually a CM, both structure and edges' weights, is composed by experts based on their experience and expectations. Naturally, the adequacy of such a model can always be questioned. However, in cases when there are historical data about some values of CM nodes coordinates, or when it is possible to conduct an experiment by feeding test signals to the system and measuring at least some of the nodes, the possibility of mathematical identification of a CM based on identification theory appears. This, of course, significantly increases credibility of the model and reliability of the results obtained based on it.

In [2] the case when all CM nodes coordinates are measured is studied. Three methods of identification, which differ in range of applicability and quality of obtained results, are considered. The first method is designed for a deterministic environment, when all CM nodes are measured precisely. The second method allows to obtain guaranteed intervals for estimates in case of limited measurement noise. However, it is applicable only for low noise level or with very well conditioned measurement matrix. The third method is the most common and is based on the least squares method. Theoretical and practical studies helped to find dependence of identification accuracy on ratio of noise to the useful signal, on duration of the observation interval, on period of duration of exciting test signals and on number of CM nodes for which these signals are fed. The regularization procedures proposed in the study ensure stability of the solutions obtained and increase the estimation accuracy when additional information about zero connections between some CM nodes is known.

However, in practice not all CM nodes are often measurable. Thus, the purpose of this article is to find a way to identify a CM when its structure is known but some of the coordinates of its nodes remain unmeasurable and the previously proposed methods cannot be applied.

\section{PROBLEM STATEMENT}

$\mathrm{CM}$ is identified in impulse process (IP) mode, i.e. during transient process in a complex system when some of its nodes are affected by disturbances (impulses). $\mathrm{CM}$ IP equation is written according to [1] as:

$$
\Delta x_{i}(k+1)=\sum_{j=1}^{n} a_{i j} \Delta x_{j}(k),
$$

where $\Delta x_{i}(k)=x_{i}(k)-x_{i}(k-1), a_{i j}$ - weight of the edge of CM connecting its $j$-th and $i$-th nodes, $n$ - number of CM nodes. In vector-matrix form expression (1) is presented as:

$$
\Delta \bar{X}(k+1)=A \Delta \bar{X}(k)
$$


where $A$ - transposed incidence matrix of CM composed of its edges' weights; $\Delta \bar{X}$ - vector of increments of nodes coordinates $x_{i}$. Difference equation (2) describes free (uncontrolled) motion of the complex system in the IP.

Suppose there is a possibility to affect some of the nodes directly via feeding external impulses to them (test or control signals). Let us have $R$ such signals, i.e. we have vector $\bar{u}$ with size $R$. Then equation of the forced motion in CM IP looks like:

$$
\Delta \bar{X}(k+1)=A \Delta \bar{X}(k)+B \bar{u}(k)
$$

where matrix $B(n \times R)$ is composed of zeros and ones in obvious way: $B=\left(\begin{array}{c}I_{R} \\ 0\end{array}\right)$ for corresponding enumeration of CM nodes in vector $\bar{X} ; I_{R}-$ unit matrix with size $R \times R$.

Suppose also that some of the coordinates $x_{i}$ are measurable and denote measurable subvector as $\bar{Y}$ (with size $M$ ). Introduce measurement equation:

$$
\Delta \bar{Y}(k)=C \Delta \bar{X}(k)
$$

where matrix $C(M \times n)$ is composed of zeros and ones in obvious way: $C=\left(\begin{array}{ll}I_{M} & 0\end{array}\right)$ for corresponding enumeration of CM nodes in vector $\bar{X}, I_{M}$-unit matrix with size $M \times M$.

Equations (3), (4) are a system of equations of a discrete dynamic system in state space.

Let number of nodes be known but existence and weight of connections between them be unknown. Then weight incidence matrix $A$ to be identified is initially filled with apriori unknown coefficients

$$
A=\left(\begin{array}{cccc}
a_{11} & a_{12} & \ldots & a_{1 n} \\
a_{21} & a_{22} & \ldots & a_{2 n} \\
\ldots & \ldots & \ldots & \ldots \\
a_{n 1} & a_{n 2} & \ldots & a_{n n}
\end{array}\right) .
$$

Identification problem is to find coefficients $a_{i j}$ during CM IP described by state space model (3), (4).

\section{IDENTIFICATION BY 4SID METHOD}

For systems identification in state space so called 4SID (subspace state space)methods [3] are usually applied. They will be adapted to the stated problem in the present article.

Suppose measurements interval is long enough. More specifically, select $N_{1}, N_{2}$ so that $N_{2} \geq N_{1}(R+M)$ and observe inputs and outputs of the system on the interval $N_{2}+N_{1}$ sampling periods. Consider the following matrices composed of inputs and outputs on this interval: 


$$
\begin{gathered}
U_{1, N_{1}}=\left[\begin{array}{cccc}
\Delta \bar{u}(0) & \Delta \bar{u}(1) & \ldots & \Delta \bar{u}\left(N_{2}-1\right) \\
\Delta \bar{u}(1) & \Delta \bar{u}(2) & \ldots & \Delta \bar{u}\left(N_{2}\right) \\
\vdots & \vdots & \ddots & \vdots \\
\Delta \bar{u}\left(N_{1}-1\right) & \Delta \bar{u}\left(N_{1}\right) & \ldots & \Delta \bar{u}\left(N_{2}+N_{1}-2\right)
\end{array}\right], \\
Y_{1, N_{1}}=\left[\begin{array}{cccc}
\Delta \bar{Y}(0) & \Delta \bar{Y}(1) & \ldots & \Delta \bar{Y}\left(N_{2}-1\right) \\
\Delta \bar{Y}(1) & \Delta \bar{Y}(2) & \ldots & \Delta \bar{Y}\left(N_{2}\right) \\
\vdots & \vdots & \ddots & \vdots \\
\Delta \bar{Y}\left(N_{1}-1\right) & \Delta \bar{Y}\left(N_{1}\right) & \ldots & \Delta \bar{Y}\left(N_{2}+N_{1}-2\right)
\end{array}\right],
\end{gathered}
$$

where testing signals $\Delta \bar{u}$ are selected in such a way that $U_{1, N_{1}}$ has full rand and is well-conditioned.It is desirable to select $N_{2}$ so that combined matrix of inputs and outputs $\left[\begin{array}{c}U_{1, N_{1}} \\ Y_{1, N_{1}}\end{array}\right]$ is not too far from square matrix.

Question of the nature of input (testing) signals is rather important. It is well known that signals of white noise type or $\delta$-functions are informative signals of infinite order. So we need to use those intervals which have input signal most similar to them. Those intervals which contain inputs which have low amplitude or are not volatile enough can be excluded.

Complex matrix $\left[\begin{array}{l}U_{1, N_{1}} \\ Y_{1, N_{1}}\end{array}\right]$ is then RQ-decomposed with the following block representation of the decomposition:

$$
\left[\begin{array}{l}
U_{1, N_{1}} \\
Y_{1, N_{1}}
\end{array}\right]=\left[\begin{array}{cc}
R_{11} & 0 \\
R_{21} & R_{22}
\end{array}\right]\left[\begin{array}{l}
Q_{1} \\
Q_{2}
\end{array}\right]
$$

For the block $R_{22} \mathrm{SVD}$-decomposition is calculated, i.e.

$$
R_{22}=U \cdot \Sigma \cdot V^{T}
$$

where $\Sigma$ - square diagonal matrix composed of singular values of $R_{22}$ on the main diagonal in decreasing order.

Let us represent the matrices in decomposition (7) in the following block form:

$$
R_{22}=\left[\begin{array}{l:l}
U_{1} & U_{2}
\end{array}\right] \cdot\left[\begin{array}{c:c}
\Sigma_{1} & 0 \\
\hdashline 0 & \Sigma_{2}
\end{array}\right] \cdot\left[\begin{array}{l}
V_{1}^{\mathrm{T}} \\
\hdashline V_{2}^{\mathrm{T}}
\end{array}\right]
$$

where matrix $U_{1}$ has size $N_{1} M \times n$, matrix $U_{2}$ has size $N_{1} M \times\left(N_{1} M-n\right)$, matrix $\Sigma_{1}-n \times n, \Sigma_{2}-\left(N_{1} M-n\right) \times\left(N_{1} M-n\right)$, matrices $V_{1}$ and $V_{2}$ have corresponding sizes. 
We will find some realization $\left(A^{\prime}, B^{\prime}, C^{\prime}\right)$ of the system (3), (4) according to the realizations theory, without trying to find original system $(A, B, C)$ at the beginning. Matrix $A^{\prime}$ is found out of the overdeterminedsystem of matrix equations

$$
U_{1}^{(1)} A^{\prime}=U_{1}^{(2)},
$$

where matrix $U_{1}^{(1)}$ is submatrix of matrix $U_{1}$ without last $M$ rows, and ma$\operatorname{trix} U_{1}^{(2)}$ is submatrix of matrix $U_{1}$ without the first $M$ rows. Shift invariance property was used to obtain (8).

Here matrix $U_{1}$ is considered to be observability matrix for some realization, as follows from the realizations theory.Then matrix $C^{\prime}$ for this realization is the matrix consisting of the first $M$ rows of matrix $U_{1}$.

To find $B^{\prime}$ let us introduce auxiliary matrix $\Xi=U_{2}^{\mathrm{T}} R_{21} R_{11}^{-1}$ (test signals should be selected so that $R_{11}$ is invertible) and solve equation

$$
\begin{gathered}
{\left[\begin{array}{cccc}
U_{2}^{\mathrm{T}}(1: M) & U_{2}^{\mathrm{T}}(M+1: 2 M) & \ldots & U_{2}^{\mathrm{T}}\left(M\left(N_{2}-1\right)+1: M N_{2}\right) \\
U_{2}^{\mathrm{T}}(M+1: 2 M) & U_{2}^{\mathrm{T}}(2 M+1: 3 M) & \ldots & 0 \\
\vdots & \vdots & \ddots & \vdots \\
U_{2}^{\mathrm{T}}\left(M\left(N_{1}-1\right)+1: M N_{1}\right) & 0 & \ldots & 0
\end{array}\right]} \\
\times\left[\begin{array}{cc}
I_{M} & 0 \\
0 & U_{1}^{(1)}
\end{array}\right] \times\left[\begin{array}{l}
0 \\
B^{\prime}
\end{array}\right]=\left[\begin{array}{l}
\Xi(1: R) \\
\Xi(R+1: 2 R) \\
\vdots \\
\Xi\left(R\left(N_{1}-1\right)+1: R N_{1}\right)
\end{array}\right],
\end{gathered}
$$

where for all matrices $D(a: b)$ denotes submatrix of matrix $D$ from the $a$-thto the $b$-th columns.

Thus, the system is identified. But for practical application of the results we need to get closer to the original realization, specifically, to such a realization where matrices $B, C$ have the form $B=\left(\begin{array}{c}I_{R} \\ 0\end{array}\right)$ and $C=\left(\begin{array}{ll}I_{M} & 0\end{array}\right)$. Equations from the realizations theory that link different realizations via non-degenerate transition matrix $T$ are helpful here:

$$
\begin{gathered}
A=T^{-1} A^{\prime} T, \\
B^{\prime}=T B, C=C^{\prime} T .
\end{gathered}
$$

To find matrix $T$, that links the original realization $(A, B, C)$ and the obtained realization $\left(A^{\prime}, B^{\prime}, C^{\prime}\right)$, we need to solve equations system (11) in which only ma$\operatorname{trix} T$ with size $n \times n$ is unknown. The system is underdetermined if number of unknown variables is higher than number of equations, i.e. in our case if 
$n^{2}>n+M$ that is almost always true. Thus, it's sufficient to find any its solution to obtain $T$, and then to calculate $A$ in the original realization from (10).

To estimate the quality of identification of the CM incidence matrix coefficients, comparison of the original and the obtained matrices $A$ is not always advisable, since 4SID method ensures output equivalence of the original and identified systems (i.e. for any identical input both models give the same response), but the method does not guarantee the identity of the state matrices realizations. Therefore, it is desirable to compare original and identified systems on the basis of some invariants that are independent on any specific realization. It is obvious from (10) that the most natural invariants are eigenvalues, which are identical for the pair $A, A^{\prime}$.

In addition to the eigenvalues, the controlled and observable system (3), (4) has other invariants that can be written in explicit form if the matrix $A$ has a realization in Jordan form (the transition to which is a standard task). For simplicity, consider the case when the system does not have multiple eigenvalues. Then the matrix $A$ has a real Jordan structure

where

$$
A=\operatorname{diag}\left(J_{1}, \ldots, J_{P}\right)
$$

$$
J_{p}=\left(\begin{array}{cc}
\alpha_{p} & -\beta_{p} \\
\beta_{p} & \alpha_{p}
\end{array}\right), p=\overline{1, P} .
$$

Here the unified form is used which combines real and complex eigenvalues. In case of real eigenvalue $\beta_{p}=0$, and respective rows and columns are removed so that $J_{p}=\alpha_{p}$. Let matrices $B$ and $C$ (when $A$ has Jordan realization) be composed of the coefficients $b_{r p}^{c}, b_{r p}^{s}, c_{m p}^{c}, c_{m p}^{s}$ according to the following rule:

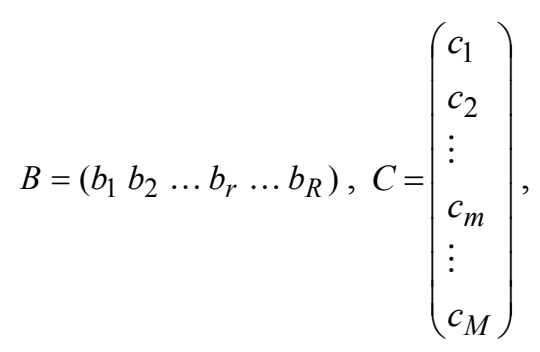

where $b_{r}$ iscolumn vector, $c_{m}$ is row vector written as $b_{r}^{T}=\left(b_{r 1}^{c} b_{r 1}^{s} b_{r 2}^{c} b_{r 2}^{s} \ldots b_{r P}^{c} b_{r P}^{s}\right), c_{m}=\left(c_{m 1}^{c} c_{m 1}^{s} c_{m 2}^{c} c_{m 2}^{s} \ldots c_{m P}^{c} c_{m P}^{s}\right)$, in case of real eigenvalues coefficients with superscript $s$ are absent.

Then the system in "input-output" form, based on Cauchy formula, is written as:

$$
y_{m}(k)=\sum_{j=0}^{k} \sum_{r=1}^{R} \sum_{p=1}^{P} h_{p}^{m r}(k-j) u_{r}(j) \quad m=\overline{1, M},
$$

where $h_{p}^{m r}(s)=\rho_{p}\left[f_{m p}^{r c} \cos \omega_{p}(s-1)+f_{m p}^{r s} \sin \omega_{p}(s-1)\right]$, 


$$
\begin{gathered}
f_{m p}^{r c}=c_{m p}^{c} b_{r p}^{c}+c_{m p}^{s} b_{r p}^{s}, \\
f_{m p}^{r s}=c_{m p}^{c} b_{r p}^{s}-c_{m p}^{s} b_{r p}^{c}, \\
\omega_{p}=\arccos \frac{\alpha_{p}}{\rho_{p}}=\arcsin \frac{\beta_{p}}{\rho_{p}}, \rho_{p}=\sqrt{\alpha_{p}^{2}+\beta_{p}^{2}} .
\end{gathered}
$$

Then figures $f_{m p}^{r c}, f_{m p}^{r s}, \quad m=1, \ldots, M, r=1, \ldots, R, p=1, \ldots, P$, calculated in (12), (13), are the invariants of the system; for real eigenvalues respective $f_{m p}^{r s}$ are absent (equal to zero).

\section{EXPERIMENTAL RESEARCH}

A set of computational research experiments was carried out using a CM of an IT company (Fig. 1) [4].

In this $\mathrm{CM}$ the following nodes are measurable: 1. Project duration. 2. Innovation expenses. 3. Salaries, bonuses. 4. Project's budget. 5. Profit. 6. Manager group expenses. 7. Marketing expenses. 8. Revenue of projects' sells. 9. Staff reassessment expenses. 10. Staff training expenses. The unmeasurable nodes are: 11. Technical control. 12. Intelligent assets. 13. Quality of a final product. 14. Competitive ability. 15. Job satisfaction. 16. Experience exchange. Test signals are fed to the nodes 2, 3, 4, 6, 7, 9 and 10 .

After having written IP equation of this CM in the state space model form (3), (4) we obtain

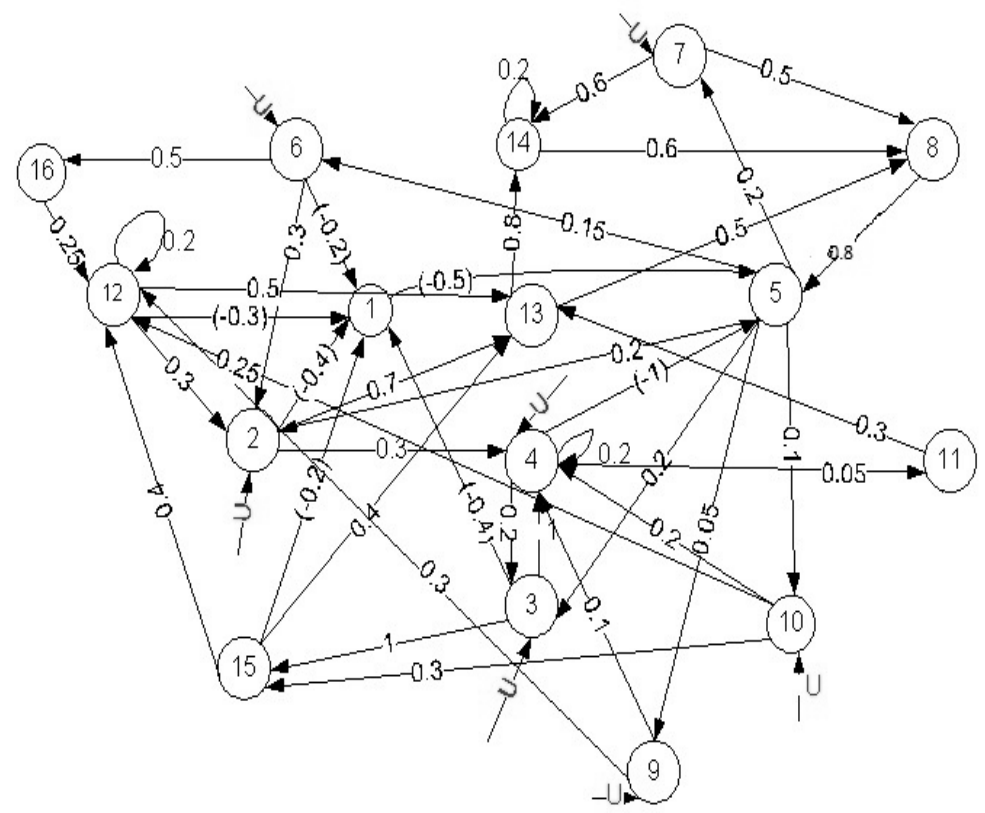

Fig. 1. CM of an IT company 


$$
A=\left(\begin{array}{cccccccccccccccc}
0 & -0,4 & -0,4 & 0 & 0 & -0,2 & 0 & 0 & 0 & 0 & 0 & -0,3 & 0 & 0 & -0,2 & 0 \\
0 & 0 & 0 & 0 & 0,2 & 0,3 & 0 & 0 & 0 & 0 & 0 & 0,3 & 0 & 0 & 0 & 0 \\
0 & 0 & 0 & 0,2 & 0,2 & 0 & 0 & 0 & 0 & 0 & 0 & 0 & 0 & 0 & 0 & 0 \\
0 & 0,3 & 1 & 0,2 & 0 & 0 & 0 & 0 & 0,1 & 0,2 & 0 & 0 & 0 & 0 & 0 & 0 \\
-0,5 & 0 & 0 & -1 & 0 & 0 & 0 & 0,8 & 0 & 0 & 0 & 0 & 0 & 0 & 0 & 0 \\
0 & 0 & 0 & 0 & 0,15 & 0 & 0 & 0 & 0 & 0 & 0 & 0 & 0 & 0 & 0 & 0 \\
0 & 0 & 0 & 0 & 0,2 & 0 & 0 & 0 & 0 & 0 & 0 & 0 & 0 & 0 & 0 & 0 \\
0 & 0 & 0 & 0 & 0 & 0 & 0,5 & 0 & 0 & 0 & 0 & 0 & 0,5 & 0,6 & 0 & 0 \\
0 & 0 & 0 & 0 & 0,05 & 0 & 0 & 0 & 0 & 0 & 0 & 0 & 0 & 0 & 0 & 0 \\
0 & 0 & 0 & 0 & 0,1 & 0 & 0 & 0 & 0 & 0 & 0 & 0 & 0 & 0 & 0 & 0 \\
0 & 0 & 0 & 0,05 & 0 & 0 & 0 & 0 & 0 & 0 & 0 & 0 & 0 & 0 & 0 & 0 \\
0 & 0 & 0 & 0 & 0 & 0 & 0 & 0 & 0,3 & 0,25 & 0 & 0,2 & 0 & 0 & 0,4 & 0,25 \\
0 & 0,7 & 0 & 0 & 0 & 0 & 0 & 0 & 0 & 0 & 0,3 & 0,5 & 0 & 0 & 0,4 & 0 \\
0 & 0 & 0 & 0 & 0 & 0 & 0,6 & 0 & 0 & 0 & 0 & 0 & 0,8 & 0,2 & 0 & 0 \\
0 & 0 & 1 & 0 & 0 & 0 & 0 & 0 & 0 & 0,3 & 0 & 0 & 0 & 0 & 0 & 0 \\
0 & 0 & 0 & 0 & 0 & 0,5 & 0 & 0 & 0 & 0 & 0 & 0 & 0 & 0 & 0 & 0
\end{array}\right),
$$$$
B=\left(\begin{array}{lllllll}
0 & 0 & 0 & 0 & 0 & 0 & 0 \\
1 & 0 & 0 & 0 & 0 & 0 & 0 \\
0 & 1 & 0 & 0 & 0 & 0 & 0 \\
0 & 0 & 1 & 0 & 0 & 0 & 0 \\
0 & 0 & 0 & 0 & 0 & 0 & 0 \\
0 & 0 & 0 & 1 & 0 & 0 & 0 \\
0 & 0 & 0 & 0 & 1 & 0 & 0 \\
0 & 0 & 0 & 0 & 0 & 0 & 0 \\
0 & 0 & 0 & 0 & 0 & 1 & 0 \\
0 & 0 & 0 & 0 & 0 & 0 & 1 \\
0 & 0 & 0 & 0 & 0 & 0 & 0 \\
0 & 0 & 0 & 0 & 0 & 0 & 0 \\
0 & 0 & 0 & 0 & 0 & 0 & 0 \\
0 & 0 & 0 & 0 & 0 & 0 & 0 \\
0 & 0 & 0 & 0 & 0 & 0 & 0 \\
0 & 0 & 0 & 0 & 0 & 0 & 0
\end{array}\right),
$$

$$
C=\left(\begin{array}{llllllllllllllll}
1 & 0 & 0 & 0 & 0 & 0 & 0 & 0 & 0 & 0 & 0 & 0 & 0 & 0 & 0 & 0 \\
0 & 1 & 0 & 0 & 0 & 0 & 0 & 0 & 0 & 0 & 0 & 0 & 0 & 0 & 0 & 0 \\
0 & 0 & 1 & 0 & 0 & 0 & 0 & 0 & 0 & 0 & 0 & 0 & 0 & 0 & 0 & 0 \\
0 & 0 & 0 & 1 & 0 & 0 & 0 & 0 & 0 & 0 & 0 & 0 & 0 & 0 & 0 & 0 \\
0 & 0 & 0 & 0 & 1 & 0 & 0 & 0 & 0 & 0 & 0 & 0 & 0 & 0 & 0 & 0 \\
0 & 0 & 0 & 0 & 0 & 1 & 0 & 0 & 0 & 0 & 0 & 0 & 0 & 0 & 0 & 0 \\
0 & 0 & 0 & 0 & 0 & 0 & 1 & 0 & 0 & 0 & 0 & 0 & 0 & 0 & 0 & 0 \\
0 & 0 & 0 & 0 & 0 & 0 & 0 & 1 & 0 & 0 & 0 & 0 & 0 & 0 & 0 & 0 \\
0 & 0 & 0 & 0 & 0 & 0 & 0 & 0 & 1 & 0 & 0 & 0 & 0 & 0 & 0 & 0 \\
0 & 0 & 0 & 0 & 0 & 0 & 0 & 0 & 0 & 1 & 0 & 0 & 0 & 0 & 0 & 0
\end{array}\right) .
$$


First, let all coordinates be measured precisely. We feed test signals in white noise form with unit variance in the 7 nodes listed above and measure 10 output CM coordinates over 500 sampling periods. First, we make sure that the outputs of the identified CM are equal to the real outputs in the IP mode (in Fig. 2 the solid line is the real system, the dotted line is the identified one, only the first 20 sampling periods are plotted).

Consider the first group of invariants - eigenvalues of the CM incidence matrix. In the original (real) system they are the following (Table 1):
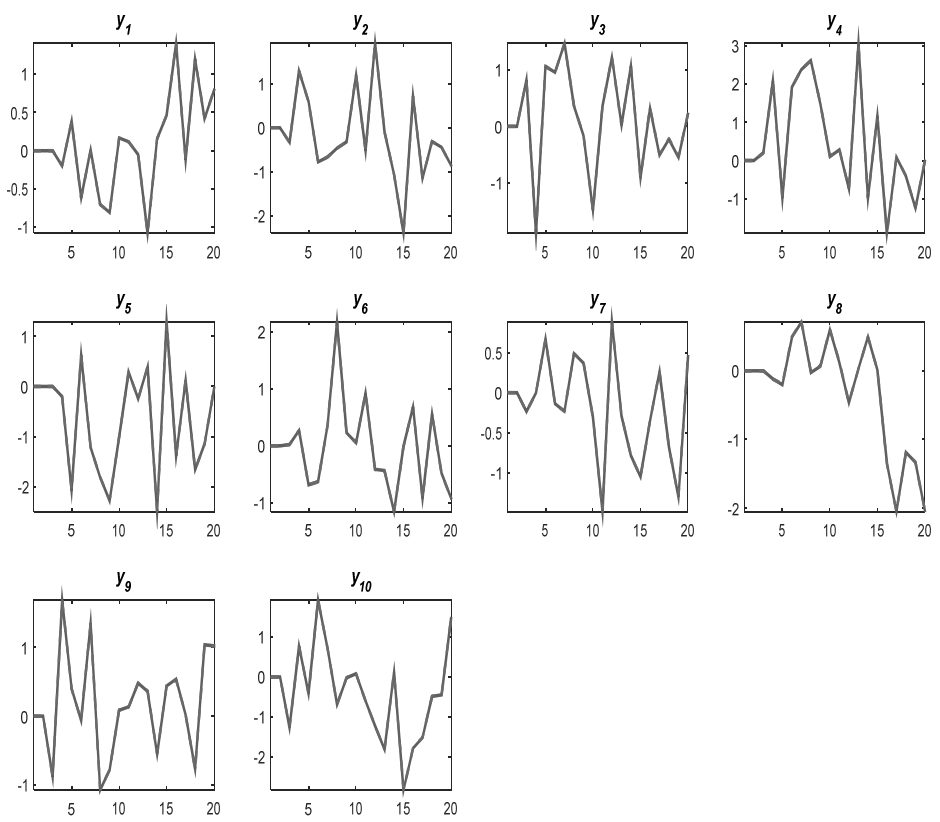

Fig. 2. Output coordinates of the original and identified CM

Table 1. Eigenvalues of the original $\mathbf{C M}$

\begin{tabular}{|l}
\hline 0.729817358793173 \\
\hline $0.288473607378827+0.545877212297539 \mathrm{i}$ \\
\hline $0.288473607378827-0.545877212297539 \mathrm{i}$ \\
\hline-0.5951684896655732 \\
\hline $0.0534731799408301+0.389920339850528 \mathrm{i}$ \\
\hline $0.0534731799408301-0.389920339850528 \mathrm{i}$ \\
\hline$-0.275361797240735+0.212821392357389 \mathrm{i}$ \\
\hline$-0.275361797240735-0.212821392357389 \mathrm{i}$ \\
\hline-0.209793520825393 \\
\hline 0.0374451042749558 \\
\hline$-1.95541830461056 \mathrm{e}-16+9.03643387627237 \mathrm{e}-10 \mathrm{i}$ \\
\hline $1.95541830461056 \mathrm{e}-16-9.03643387627237 \mathrm{e}-10 \mathrm{i}$ \\
\hline$-2.82703848340360 \mathrm{e}-16$ \\
\hline $7.56176002022082 \mathrm{e}-17$ \\
\hline
\end{tabular}


It is likely that the last 5 eigenvalues from Table 1 are actually zero of multiplicity 5; this significantly complicates comparison of the invariants. Therefore, we will first of all consider the first 11 eigenvalues in the analysis because they mostly characterize the CM IP dynamics.

We will compare the invariant vector of eigenvalues of the identified and the original CM under different conditions. The following metric is suggested for comparison. Both vectors are sorted by absolute values, their difference is found and the maximum absolute value of the difference vector is calculated. In case when the structure of eigenvalues is not violated this metric reflects maximum deviation of the obtained values from the original ones.

The dependence of the suggested metric on the number of measured coordinates is shown (Fig. 3). For reliability of the research results, 10 models (with different inputs) were built and then averaged. With 10 measured coordinates (as in the example described above), the error is 0.0067 , which can be seen as quite satisfactory. When the number of measured nodes is 4 or less, the error grows significantly.

The dependence of the same performance metric (based on the accuracy of eigenvalues identification) on the number of measurements (also after averaging over 10 models) is shown (Fig. 4). The number of measured nodes is 10 . The error is 0.059 for 500 measurements (sampling periods). A significant raise of the error starts when number of measurements is less than 400 .

The dependence on measurement noise (in previous studies it was assumed to be zero) is shown (Fig. 5). We feed uniformly distributed random noise (with amplitude depending on the maximum value of the useful signal) to all the measured nodes. So we will investigate dependence of the identification error on the noise to the useful signal ratio (with 500 measurements of 10 coordinates).

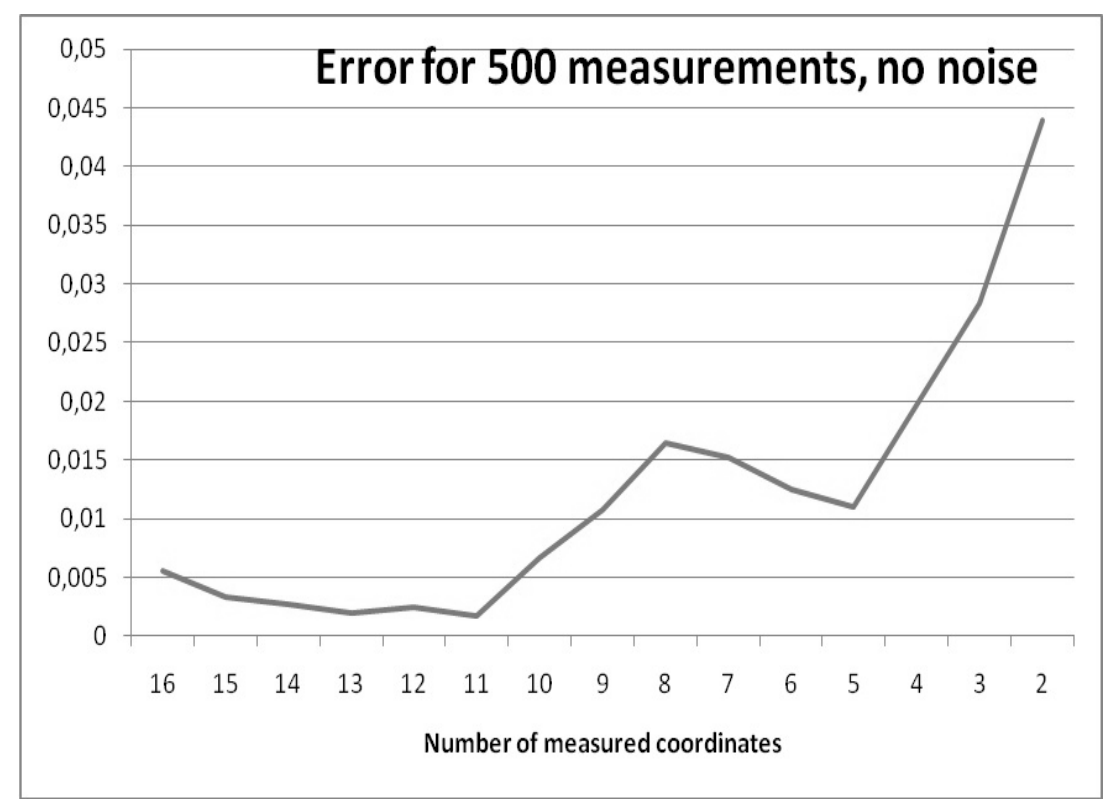

Fig. 3. Identification error vs number of measured coordinates 


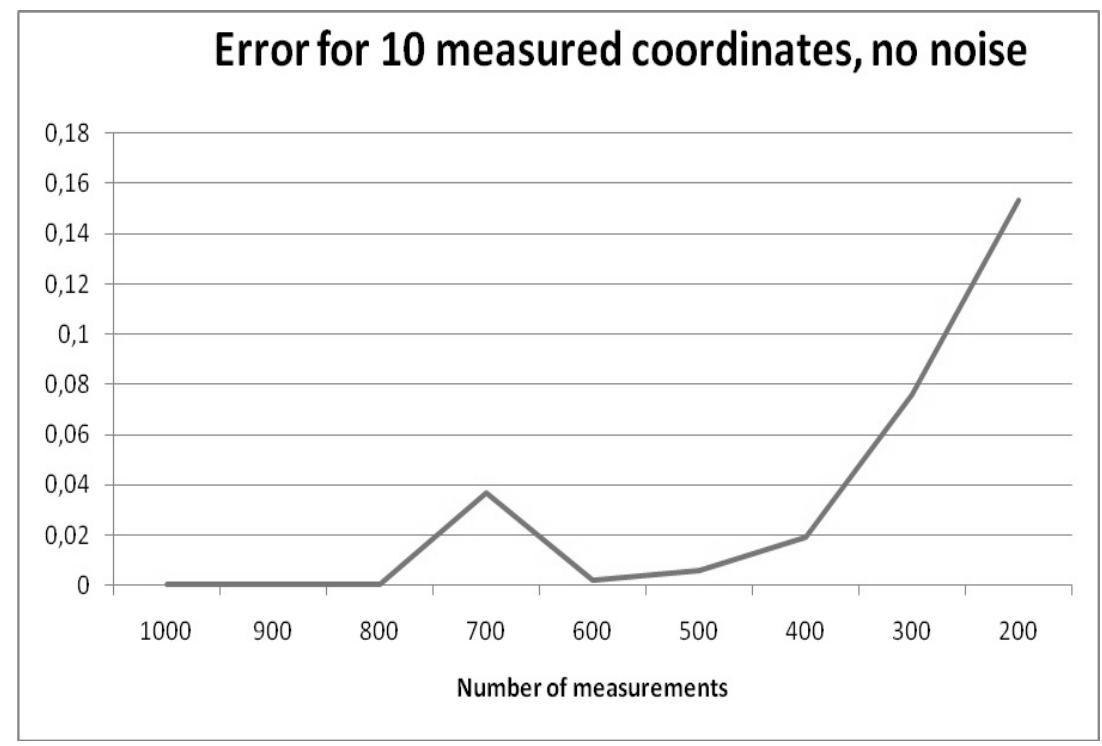

Fig. 4. Identification error vs number of measurements

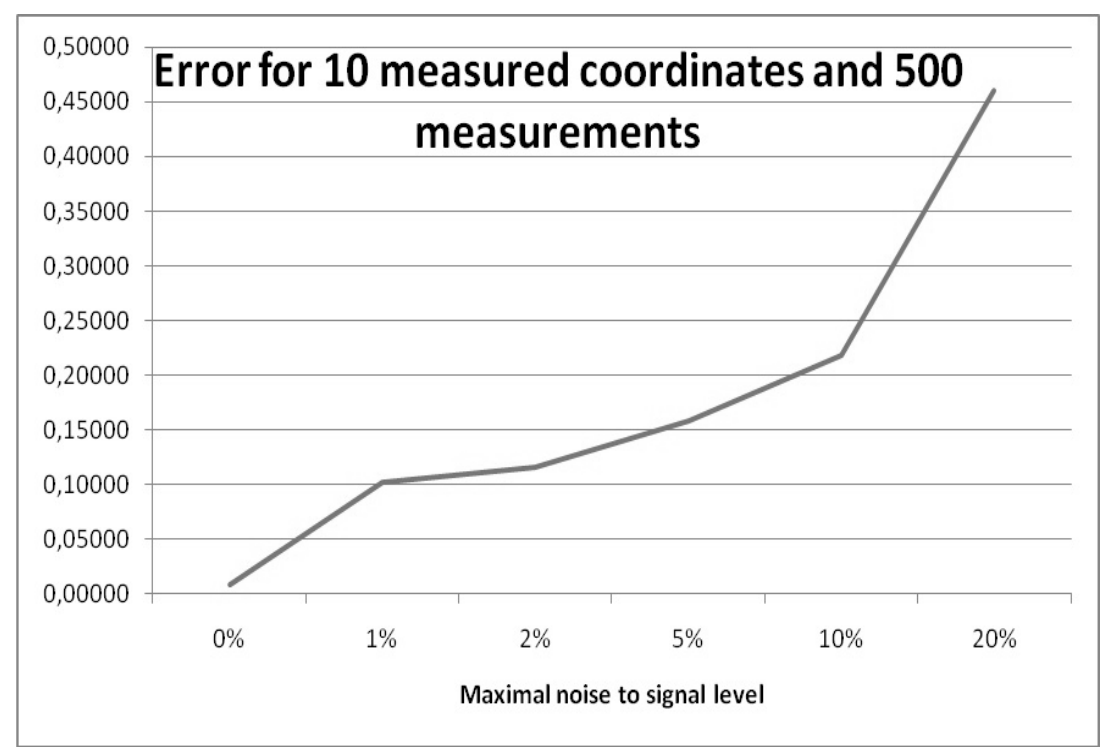

Fig. 5. Identification error vs noise to signal level

The dependence on measurement noise is especially important, so we present the results also in tabular form (Table 2). Here we calculate not the maximum error metric suggested above, but the identified modes of the system themselves. The absolute values of the noise amplitude are in the table header. 
Table 2. Eigenvalues of the identified CM

\begin{tabular}{|c|c|c|c|}
\hline $\mathbf{0}$ & $1.00 \mathrm{E}-14$ & $1.00 \mathrm{E}-10$ & $1.00 \mathrm{E}-05$ \\
\hline $\begin{array}{c}0.729990838616750+ \\
0.00000000000000 \mathrm{i}\end{array}$ & $\begin{array}{c}0.729990838616752+ \\
0.00000000000000 \mathrm{i}\end{array}$ & $\begin{array}{c}0.729795701554137+ \\
0.00000000000000 \mathrm{i}\end{array}$ & $\begin{array}{c}0.729991153904236+ \\
0.00000000000000 \mathrm{i}\end{array}$ \\
\hline $\begin{array}{c}0.288527551393047+ \\
0.546013552369764 \mathrm{i}\end{array}$ & $\begin{array}{c}0.504361922199503+ \\
0.00000000000000 \mathrm{i}\end{array}$ & $\begin{array}{c}0.288425185463485+ \\
0.545841676379809 \mathrm{i}\end{array}$ & $\begin{array}{c}0.288525198162765+ \\
0.546013875258183 \mathrm{i}\end{array}$ \\
\hline $\begin{array}{l}0.288527551393047- \\
0.546013552369764 \mathrm{i}\end{array}$ & $\begin{array}{c}0.288527551393046+ \\
0.546013552369763 \mathrm{i}\end{array}$ & $\begin{array}{c}0.288425185463485- \\
0.545841676379809 \mathrm{i}\end{array}$ & $\begin{array}{l}0.288525198162765- \\
0.546013875258183 i\end{array}$ \\
\hline $\begin{array}{c}0.504361922199501+ \\
0.00000000000000 \mathrm{i}\end{array}$ & $\begin{array}{c}0.288527551393046- \\
0.546013552369763 \mathrm{i}\end{array}$ & $\begin{array}{c}0.504727440971184+ \\
0.00000000000000 \mathrm{i}\end{array}$ & $\begin{array}{c}0.504362027516735+ \\
0.00000000000000 \mathrm{i}\end{array}$ \\
\hline $\begin{array}{c}-0.595167227890913+ \\
0.00000000000000 \mathrm{i}\end{array}$ & $\begin{array}{c}-0.595167227890916+ \\
0.00000000000000 \mathrm{i}\end{array}$ & $\begin{array}{c}-0.595212059904572+ \\
0.00000000000000 \mathrm{i}\end{array}$ & $\begin{array}{c}-0.595168251524833+ \\
0.00000000000000 \mathrm{i}\end{array}$ \\
\hline $\begin{array}{c}0.0534059512435629+ \\
0.389763957407337 \mathrm{i}\end{array}$ & $\begin{array}{c}0.0534059512435720+ \\
0.389763957407340 \mathrm{i}\end{array}$ & $\begin{array}{c}0.0531856330760910+ \\
0.389823025408581 \mathrm{i}\end{array}$ & $\begin{array}{c}0.0534124939792743+ \\
0.389765316747699 \mathrm{i}\end{array}$ \\
\hline $\begin{array}{c}0.0534059512435629- \\
0.389763957407337 \mathrm{i}\end{array}$ & $\begin{array}{c}0.0534059512435720- \\
0.389763957407340 \mathrm{i}\end{array}$ & $\begin{array}{c}0.0531856330760910- \\
0.389823025408581 \mathrm{i}\end{array}$ & $\begin{array}{c}0.0534124939792743- \\
0.389765316747699 \mathrm{i}\end{array}$ \\
\hline $\begin{array}{c}-0.275098990019907+ \\
0.213125022452357 \mathrm{i}\end{array}$ & $\begin{array}{c}-0.275098990019885+ \\
0.213125022452346 \mathrm{i}\end{array}$ & $\begin{array}{c}-0.275481781185811+ \\
0.212239094334225 \mathrm{i}\end{array}$ & $\begin{array}{c}-0.275078260183521+ \\
0.213111222276663 \mathrm{i}\end{array}$ \\
\hline $\begin{array}{c}-0.275098990019907- \\
0.213125022452357 \mathrm{i}\end{array}$ & $\begin{array}{c}-0.275098990019885- \\
0.213125022452346 \mathrm{i}\end{array}$ & $\begin{array}{c}-0.275481781185811- \\
0.212239094334225 \mathrm{i}\end{array}$ & $\begin{array}{c}-0.275078260183521- \\
0.213111222276663 \mathrm{i}\end{array}$ \\
\hline $\begin{array}{c}-0.211145050250800+ \\
0.00000000000000 \mathrm{i}\end{array}$ & $\begin{array}{c}-0.211145050250820+ \\
0.00000000000000 \mathrm{i}\end{array}$ & $\begin{array}{c}-0.208941997309267+ \\
0.00000000000000 \mathrm{i}\end{array}$ & $\begin{array}{c}-0.211156370940011+ \\
0.00000000000000 \mathrm{i}\end{array}$ \\
\hline $\begin{array}{c}0.0374188299453503+ \\
0.00000000000000 \mathrm{i}\end{array}$ & $\begin{array}{c}0.0374188299453380+ \\
0.00000000000000 \mathrm{i}\end{array}$ & $\begin{array}{c}0.0374653239841545+ \\
0.00000000000000 \mathrm{i}\end{array}$ & $\begin{array}{c}0.0374077126848873+ \\
0.00000000000000 \mathrm{i}\end{array}$ \\
\hline $\begin{array}{c}0.000853598779548921 \\
0.00000000000000 \mathrm{i}\end{array}$ & $\begin{array}{c}0.000853598779766390+ \\
0.00000000000000 \mathrm{i}\end{array}$ & $\begin{array}{l}-0.00808130305896758 \\
+0.00000000000000 \mathrm{i}\end{array}$ & $\begin{array}{c}-0.00137761954985350+ \\
0.00000000000000 \mathrm{i}\end{array}$ \\
\hline $\begin{array}{c}-0.000765459607735681 \\
+0.00000000000000 \mathrm{i}\end{array}$ & $\begin{array}{c}-0.000765459608667301 \\
+0.00000000000000 \mathrm{i}\end{array}$ & $\begin{array}{c}0.00770399293877252+ \\
0.00000000000000 \mathrm{i}\end{array}$ & $\begin{array}{c}0.00100933752150903+ \\
0.00000000000000 \mathrm{i}\end{array}$ \\
\hline $\begin{array}{c}-3.46232972558093 \mathrm{e}-13+ \\
0.00000000000000 \mathrm{i}\end{array}$ & $\begin{array}{c}-1.14730616044168 \mathrm{e}-15+ \\
0.00000000000000 \mathrm{i}\end{array}$ & $\begin{array}{c}3.62004525836301 \mathrm{e}-10 \\
+0.00000000000000 \mathrm{i}\end{array}$ & $\begin{array}{c}0.000244542992428858+ \\
0.00000000000000 \mathrm{i}\end{array}$ \\
\hline $\begin{array}{c}-8.38294372987105 \mathrm{e}-15+ \\
0.00000000000000 \mathrm{i}\end{array}$ & $\begin{array}{c}5.45925393953776 \mathrm{e}-14+ \\
3.19610528245246 \mathrm{e}-14 \mathrm{i}\end{array}$ & $\begin{array}{l}-2.45971146842435 \mathrm{e}-11 \\
+0.00000000000000 \mathrm{i}\end{array}$ & $\begin{array}{c}1.07321950169192 \mathrm{e}-06+ \\
0.00000000000000 \mathrm{i}\end{array}$ \\
\hline $\begin{array}{c}-9.65897357673646 \mathrm{e}-17+ \\
0.00000000000000 \mathrm{i}\end{array}$ & $\begin{array}{l}5.45925393953776 \mathrm{e}-14- \\
3.19610528245246 \mathrm{e}-14 \mathrm{i}\end{array}$ & $\begin{array}{l}-1.43698326020234 \mathrm{e}-11 \\
+0.00000000000000 \mathrm{i}\end{array}$ & $\begin{array}{c}6.04341025062634 \mathrm{e}-06+ \\
0.00000000000000 \mathrm{i}\end{array}$ \\
\hline
\end{tabular}

So, starting from the noise with order of values around $10^{-5}$ the error in some modes becomes significant; after that the structure of eigenvalues is broken (complex pairs turn into real eigenvalues etc.).

Invariants of the second group were also calculated based on the formulas (12), (13). The total number of these invariants is very large: for example, if we consider 10 measured coordinates, with 7 test signals we get 1120 invariants. 
Therefore, the results of the analysis based on them are not shown in the article. However, in general it should be said that a noticeable discrepancy between these invariants for the identified and the original systems also starts at noise level around $10^{-5}$.

\section{IDENTIFICATION OF A COGNITIVE MAP WITH UNMEASURABLE NODES}

The paper studies the problem of identifying weight coefficients of the CM incidence matrix under the condition that some of its nodes are not measurable. For this purpose 4SID method is used, which allows, firstly, to find some realization of the system in state space, and, secondly, to get back closer to the original realization, which has the specific type of control and observation matrices. The identified and original systems are identical in output, i.e. measured coordinates response identically to the same input test signals. Quality of the identification was thoroughly analyzed by comparing groups of invariants of the original and identified systems. The practical example of the IT company's CM was analyzed. The analysis confirmed applicability of the suggested identification method and helped to find its limitations.

\section{CONCLUSIONS}

As a result of the research, it can be concluded that the identification method for a CM in IP mode is efficient, but only under certain conditions and limitations. Its efficiency severely depends on number of measurements, number of measured nodes coordinates and especially on measurements noise. In fact, even without measurement noise, identification is not completely accurate because of the computational error, which is essential for multivariate complex systems (e.g., a 16-dimensional CM). When noise exceeds a certain threshold (about $10^{-5}$ in this case, but in general it depends on the structure of the CM), accurate identification becomes impossible. This is not a disadvantage of the suggested method, but an inevitable property of any identification method, since, starting from a certain threshold, the problem becomes incorrect (ill-posed). Thus, the 4SID method is recommended to be used for CM identification with a sufficient number of measurements with low noise. A general case method will be developed in further research.

\section{REFERENCES}

1. Roberts F. Discrete Mathematical Models with Applications to Social, Biological, and Environmental Problems. Englewood Cliffs: Prentice-Hall, 1976. 559p.

2. V. Gubarev, V. Romanenko, Y. Milyavsky. Identification in cognitive maps in the impulse process mode with full information.Problems of control and informatics. 2018. № 4. P. 30-43 (in Russian).

3. Verhagen M., Dewilde P., Subspace model identification. Part I: the output-error state space model identification class of algorithms. Int. J. Control. 1992,. №56. P. 1187-1210.

4. V. Romanenko, Y. Milyavsky, M. Polyakov, Y. Letser, G. Shevchenko. Research of scenarios of IT company development based on decision-making in cognitive maps impulse process control mode. Proceedings of $1^{\text {st }}$ international scientific and practical forum "Science and business". (29-30 of June, 2015, Dnipropetrovsk), Dnipropetrovsk, 2015. P. 233-237.2015. P. 233-237 (in Russian). 


\section{ЛИТЕРАТУРА}

1. Roberts F. Discrete Mathematical Models with Applications to Social, Biological, and Environmental Problems. Englewood Cliffs: Prentice-Hall, 1976. 559 p.

2. В.Ф. Губарев, В.Д. Романенко, Ю.Л. Милявский. Идентификация в когнитивных картах в режиме импульсных процессов при полной информации. Проблемьь управления и информатики. 2018. № 4. С. 30-43.

3. Verhagen M., Dewilde P., Subspace model identification. Part I: the output-error state space model identification class of algorithms. Int. J. Control. 1992. № 56. P. 1187-1210.

4. Романенко В.Д., Милявский Ю.Л., Поляков М.В., Лецер Ю.А., Шевченко Г.Я. Исследование сценариев развития ИТ-компании на основе принятия решений в режиме управления импульсными процессами когнитивных карт. Тезисы докладов 1-го международного научно-практического форума "Наука и бизнес", 29-30 июня, 2015, г. Днепропетровск). Днепропетровск, 2015 г. С. 233-237.

Получено 27.11.2018

Мілявський Ю.Л., старший викладач

кафедри математичних методів системного аналізу

e-mail: yuriy.milyavsky@gmail.com

Національний технічний університет України

«Київський політехнічний інститут ім. І. Сікорського»,

пр. Перемоги, 37, Київ, 03056, Україна

\section{ІДЕНТИФІКАЦІЯ В КОГНІТИВНИХ КАРТАХ У РЕЖИМІ ІМПУЛЬСНИХ ПРОЦЕСІВ ЗА УМОВИ НЕПОВНОГО ВИМІРЮВАННЯ КООРДИНАТ ВЕРШИН}

Вступ. Когнітивна карта - популярний спосіб моделювання складних багатозв'язних систем. Зазвичай вагові коефіцієнти ребер, що зв'язують вершини когнітивної карти, визначаються експертами. Але таке визначення завжди $\epsilon$ неточним. У разі, якщо координати вершин вимірюються, є можливість здійснити математичну ідентифікацію цих коефіцієнтів. Однак проблема полягає в тому, що дуже часто вимірюються не всі координати вершин когнітивної карти, а лише деякі з них. В цьому разі задача ідентифікації значно ускладнюється.

Метою статті є розроблення і дослідження методу ідентифікації вагових коефіцієнтів ребер когнітивної карти у випадку, коли кількість вершин карти відома, але не усі 3 них вимірюються.

Результати. Запропоновано метод ідентифікації, що базується на 4SID методі (методі виділеного підпростору). Цей метод дає змогу знайти деяку реалізацію системи, еквівалентну за виходом з початковою когнітивною картою, водночас матриці керування та спостереження залишаються без змін. Проаналізовано інваріанти вихідної та ідентифікованої систем. Розглянуто практичний приклад ідентифікації когнітивної карти IT компанії. Показано, від чого залежить точність запропонованого методу та за яких умов його можна застосовувати.

Висновки. Як показало дослідження, в результаті ідентифікації когнітивних карт запропонованим методом було досягнуто практично повного збігу за вимірюваними координатами між початковою та ідентифікованою системами, хоча самі матриці суміжності можуть не співпадати. Інваріанти системи, зокрема власні числа, ідентифікуються достатньо точно, якщо задачу добре зумовлено, тобто за достатньої кількості вимірюваних координат, достатньої кількості інтервалів вимірювань та за умови невеликого рівня шуму вимірювань. Якщо ці умови не виконуються, результати ідентифікації стають некоректними. 
Ключові слова: когнітивна карта, ідентифікація, метод виділеного підпростору, невимірювані координати.

Милявский Ю.Л., старший преподаватель кафедры математических методов системного анализа e-mail: yuriy.milyavsky@gmail.com Национальний технический университет Украины «Киевський политехнический институт им. И. Сикорского», пр. Победы, 37, Киев, 03056, Украина

\section{ИДЕНТИФИКАЦИЯ В КОГНИТИВНЫХ КАРТАХ В РЕЖИМЕ ИМПУЛЬСНЫХ ПРОЦЕССОВ ПРИ НЕПОЛНОМ ИЗМЕРЕНИИ КООРДИНАТ ВЕРШИН}

Исследована задача идентификации весовых коэффициентов матриц смежности когнитивных карт в случае, когда часть координат вершин не измеряется. Предложен метод идентификации, основывающийся на 4SID методе. Проанализированы инварианты исходной и идентифицированной систем. Рассмотрен практический пример идентификации когнитивной карты IT компании. Показано, при каких условиях предложенный метод применим.

Ключевые слова: когнитивная карта, идентификачия, метод выделяемого подпространства, неизмеряемые координаты. 